\title{
Gender power relations in reproductive decision-making: The case of Gamo migrants in Addis Ababa, Ethiopia
}

\author{
Tefera Darge Delbiso \\ Lecturer, Hawassa University, Ethiopia \\ P.O.Box 05, Hawassa, Ethiopia \\ teferadarge@gmail.com
}

\begin{abstract}
In many developing countries most reproductive decisions are made by men although it is, as well, the concern of women. This study was undertaken with the objective of assessing gender power relations in reproductive decision-making (DM). Data was collected from a random sample of 317 married couples using a structured questionnaire. Multinomial logistic regression was used to find the determinants of reproductive DM. Accordingly, 33\% of women reported joint contraceptive use DM; $36 \%$ of women and $38 \%$ of men reported joint maternal health service utilization (MHSU) DM. Women who are older, literate, have fewer children, media access, have job, and not victims of harassment/abuse participate in reproductive DM, while men who are literate, have fewer children, media access, older, and did not harass/abuse their wives let wives participate in MHSU DM. Thus, empowering the study community in general and women in particular is recommended to improve their participation in reproductive DM.
\end{abstract}

Keywords: Decision-making; gender; power relations; contraceptives use; maternal health service utilization.

\section{Résumé}

Dans de nombreux pays en développement, la plupart des décisions en matière de reproduction sont faits par des hommes bien qu'il soit ainsi, les préoccupations des femmes. Cette étude a été réalisée dans le but d'évaluer les relations de pouvoir entre les sexes dans la reproduction de décision. Les données recueillies à partir de l'échantillon aléatoire de 317 couples mariés, à l'aide de questionnaire structuré. Régression logistique multinomiale a été utilisé pour trouver les déterminants de la reproduction décision. En conséquence, 33\% des femmes ont signalé l'utilisation conjointe des contraceptifs prise de décision; $36 \%$ des femmes et $38 \%$ des hommes ont déclaré la santé l'utilisation des services de prise de décision conjointe de la mère. Les femmes qui sont plus âgés, cultivé, avoir moins d'enfants, l'accès aux médias, avoir travail, et pas victime de harcèlement / abus participer à la reproduction de décision, tandis que les hommes qui savent lire et écrire, ont moins d'enfants, l'accès aux médias, les personnes âgées, et ne pas harceler / abusent de leurs épouses Que les femmes participent à l'utilisation des services de santé maternelle de décision. Ainsi, l'autonomisation de la communauté d'étude en général et les femmes en particulier est recommandé d'améliorer leur participation à la reproduction de décision.

Mots-clés: prise de décision, le sexe, les relations de pouvoir; contraceptifs utilisation; utilisation des services de santé maternelle.

\section{Introduction}

In most societies, women usually have less power than men in all spheres of life (Eguavoen et al. 2007). The patriarchal, hierarchical and polygynous organization of many African households, the young age at marriage for women, patrilocal residence after marriage, the large age difference between spouses, the unequal work burden between the sexes, the high bride price, and the low educational level of women tends to perpetuate the low status of women and make them voiceless and powerless in all spheres of life including sexuality and reproduction (Makinwa-Adebusoye 200I; Boserup 1985). Consequently, women's needs and preferences are neglected, and their knowledge and experience are not used to help guide decisions in their family as well as in their community (Kuponiyi and Alade 2007; Arkutu 1995). Accordingly, in many developing countries, most 
decisions regarding sexual activity, fertility, and contraceptive use are made by men (Oladeji 2008).

The situation is similar in Ethiopia, where women generally do not have equal rights with their husbands to access resources, to make decisions regarding their desired number of children, to use contraception and even to space or stop childbearing (Olokodana and Yeshi 1998). As a result, women's DM abilities remain constrained and subjugated to the political, socioeconomic and cultural dominance of men (WHO 1999). The consequent gender based power inequalities hinder communication between partners about reproductive health decisions, constrains their access to reproductive health services, prevents them from attaining the highest level of sexual health and pleasure and this, in turn, contributes greatly to poor health outcomes (Blanc 200I; Speizer, Whittle and Carter 2005).

Understanding women's reproductive needs and identifying the key factors which influence reproductive negotiation processes between husband and wife are necessary to formulate policies aimed at creating a conducive environment to improve women's reproductive health, general well-being and their decision-making power (Xu 1999). Furthermore, realizing the linkage between gender power relations and reproductive DM is among the key factors which can help assess the extent of gender inequality. However, studies in the area of gender power relations nexus reproductive DM are limited in Ethiopia. Thus, this study was aimed to fill the knowledge gap by using data collected from the Gamo community in Addis Ababa who are migrants from the Gamo Gofa zone of Southern Ethiopia.

The Gamo community migrates to urban centers to engage in the weaving business since much of the demand for woven goods is concentrated in urban areas. Weaving is the means of livelihood for the majority of Gamo's in Addis Ababa. Traditionally, women spin the cotton and men do the weaving, and it is the sole source of income for these people. This community usually maintains their tradition and culture, and almost all live in the same localities in the city.
Moreover, the majority lead the same lifestyle as that of their place of origin, Gamo Gofa.

The weaving sector is characterized by low and fluctuating income, little access to markets and finance. Hence, to secure the livelihood of the family, women of the Gamo community are actively engaged in income generating activities in parallel to the domestic (reproductive) activities. With these background factors, the research tried to answer whether women in the study community participate in reproductive DM process as they take the lion's share of productive as well as reproductive activities in their households. Thus, the main research questions are who is responsible for reproductive DM in the household, and what are the determinants of reproductive DM in the household?

\section{Data and methodology}

\section{Sampling and data collection methods}

Among ten sub-cities in Addis Ababa, the study site, Gulele sub-city, was purposely selected for the reason that the majority of weavers are living there. A multistage sampling procedure was employed to select the study respondents. Of ten kebele (the smallest administrative unit in Ethiopia) in Gulele sub-city, a large concentration of weavers resides in two of the kebeles; namely kebele 18 and 19. In the first stage, two clusters were formed using the two kebeles. Using simple random sampling, one of the clusters, kebele 18, was chosen. In the second stage every tenth household from the selected kebele was chosen. Then from each household both wife and husband were interviewed independently. The inclusion criteria for the study respondents were: the couples should be living together in Addis Ababa during the time of the survey, the couples should be migrants from Gamo Gofa zone of Southern Ethiopia, women should be in the reproductive age category (1549 years) and men should be in the 15-59 years age category. The sample size was determined using the formula:

$n=\operatorname{Deff}\left(\frac{\frac{\square}{2}}{e}\right)^{2} p q$

where Deff is the design effect $=1.5$; is level of 
significance $=5 \%$; ies level of precision $=5 \%$;

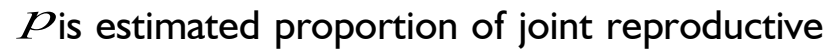
DM and estimated to be $50 \%(0.5)$. Substituting the values in the above formula and by adding $10 \%$ contingency for non-response, a sample of size 317 couples, i.e. 634 individuals, was selected. Then the data were collected by using a well designed structured questionnaire. The questionnaire contains demographic, socio-economic and cultural variables together with questions of reproductive issues and patterns of reproductive DM. The data collection was undertaken from February 09, 2009 to February 16, 2009. The response rate of the questionnaire was $100 \%$.

Ethical clearance was obtained from Addis Ababa University, Institute of Population Studies. All the study participants were informed of the purpose of the study, their right to refuse and assured confidentiality. Informed verbal consent was obtained from the respondents prior to the interview.

\section{Variables in the study}

The response variable of the study is the pattern of reproductive DM (decisions regarding contraceptive use, and MHSU). All sampled respondents were asked the questions: "Who actually makes the contraceptive use decision in your household?" and "Who actually makes the maternal health service utilization (antenatal and delivery care) decision in your household?" The possible responses for the questions are husband, wife, and joint. Then the response is categorized into three as: men-centered/husbanddominated, women-centered/wife-dominated andipint Explanatory variables included in the study are: age (15-24, 25-34 and 35+ years), religion (Orthodox Christian and Protestant), literacy status (literate and illiterate), working status (working and not-working), number of children (0, I-2 and $3+$ children), media exposure (have access and no access), physical harassment or verbal abuse (committed and not committed) and years lived in Addis Ababa (<II, II-20 and $20+$ years).

\section{Data analysis methods}

Multinomial logistic regression was fitted to identify the determinant factors (adjusted effect) of reproductive DM. Multicollinearity, a model adequacy test, was checked using variance infla- tion factor (VIF). Besides, standardized residuals were plotted against the predicted probabilities to detect the presence of outliers and influential values; and the independence of irrelevant observations (IIA) assumption was addressed by making the outcome categories distinct and independent.

Then age, literacy status, number of children, work status, media exposure, religion, harassment/abuse and number of years lived in Addis Ababa of couples were included in the model. Finally, the relative risk ratios (RRR) and $P$-values were reported for each variable in the final model. The statistical analysis was performed using STATA/IC 10 for Window and SPSS version I 5 .

\section{Results}

\section{Sample characteristics}

The mean age of the wives was 27.3 years with standard deviation (S.D) of 5.9 years; that of their husbands was 33.5 with S.D of I0.I years. On the average husbands were six years older than their wives. About 12 percent of the couples do not have children while 46 percent have one or two children and the remaining 42 percent have three or more children. On average a couple had 2.88 children. Regarding literacy status, 66 percent of women and 30 percent of men were illiterate while the remaining 34 percent of women and 70 percent of men are literate. This shows the low educational status of the study community, and also the discrepancy between couples. As to their religious affiliation, about 68 percent and 74 percent of women and men, respectively, were Orthodox Christians and 32 percent and 26 percent of women and men, respectively, were Protestants. About 57 percent of women were engaged in income generating activities and the remainder were not. All men respondents were primarily engaged in the weaving activity and generated their own income. The media exposure indicated that about 58 percent of women had no access and the rest had access, whereas about 95 percent of men had media access and the remainder had none. Women are more disadvantaged than men in media consumption. 
Table I Sample characteristics of Gamo migrant weavers in Addis Ababa, 2009.

\begin{tabular}{|c|c|c|c|c|}
\hline \multirow[b]{2}{*}{ Characteristics } & \multicolumn{2}{|c|}{ Women $(n=317)$} & \multicolumn{2}{|c|}{ Men $(n=3 \mid 7)$} \\
\hline & $\%$ & Mean (S.D) & $\%$ & Mean (S.D) \\
\hline Age & & $27.3(5.9)$ & & $33.5(10.1)$ \\
\hline $15-24$ & 33.1 & & 14.5 & \\
\hline $25-34$ & $5 I .1$ & & 45.4 & \\
\hline $35+$ & 15.8 & & 40.1 & \\
\hline \multicolumn{5}{|l|}{ Literacy status } \\
\hline Illiterate & 65.9 & & 30.0 & \\
\hline Literate & 34.1 & & 70.0 & \\
\hline \multicolumn{5}{|c|}{ Number of children } \\
\hline No child & 12.0 & & 11.0 & \\
\hline $1-2$ & 47.3 & & 44.8 & \\
\hline $3+$ & 40.7 & & 44.2 & \\
\hline \multicolumn{5}{|l|}{ Religion } \\
\hline Orthodox & 68.1 & & 74.1 & \\
\hline Protestant & 31.9 & & 25.9 & \\
\hline \multicolumn{5}{|l|}{ Media exposure } \\
\hline Have access & 42.6 & & 95.3 & \\
\hline No access & 57.4 & & 4.7 & \\
\hline \multicolumn{5}{|l|}{ Work status } \\
\hline Working & 57.1 & & 100.0 & \\
\hline Not working & 42.9 & & 0.0 & \\
\hline \multicolumn{5}{|c|}{ Harassment/abuse } \\
\hline Committed & 69.1 & & 23.7 & \\
\hline Not committed & 30.9 & & 76.3 & \\
\hline \multicolumn{5}{|c|}{ Years lived in Addis Ababa } \\
\hline Below II & 49.2 & & 18.6 & \\
\hline $11-20$ & 30.3 & & 41.6 & \\
\hline $20+$ & 20.5 & & 39.8 & \\
\hline
\end{tabular}

Note: age $35+$ is $(35$ - 49) for women and (35 - 59) for men

The majority of surveyed women (69 percent) claimed that their husbands committed physical harassment or verbal abuse, while the remaining 31 percent reported that they had never been harassed or abused. Whereas about 24 percent of men respondents reported that they have harassed or abused their wives, the rest have never harassed or abused them. About 49 percent, 30 percent and 21 percent of women have been living in Addis Ababa for less than II years, II-20 years and more than 20 years respectively, while about 18 percent, 42 percent and 40 percent were the respective figures for men respondents (see Table I).

\section{Pattern of Reproductive DM}

The survey result showed that about 60 percent of women respondents have ever used modern contraceptive methods (Injectables, Pill, IUCDs, and Implants). Besides, of the 15 percent contraceptive users of men, the majority (96 percent) used the traditional method (periodic abstinence) and 6 percent used condom. As to the maternal health service utilization, about 69 percent have obtained antenatal care from health centers, and only 20 percent were assisted by health professionals for their last delivery. 


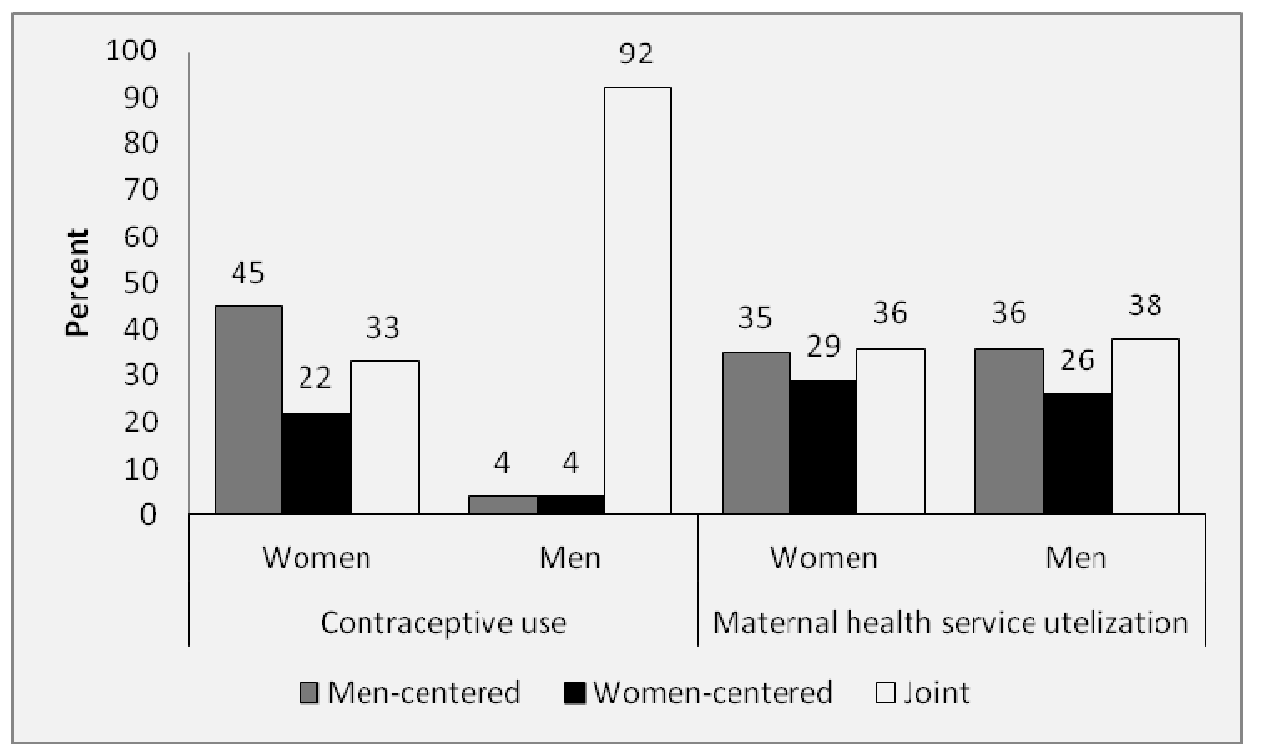

Figure 1: Pattern of reproductive DM among sample of Gamo migrant weavers in

Addis Ababa, 2009.

Regarding the contraceptive use DM, about 45 percent of women respondents reported that the decision was made by their husbands, 33 percent were made jointly and 22 percent by women themselves. An overwhelming majority (92 percent) of men respondents declared that they made the contraceptive decision in consensus with their wives. For the MHSU, a slightly large proportion of respondents were living in a household in which joint DM is practised (36 percent among women sampled and 38 percent among men) followed by men-dominated DM (35 percent among women and 36 percent among men) and women-dominated DM (29 percent among women and 26 percent among men) (see Figure I).

\section{Determinants of reproductive DM}

Multinomial logistic regression analysis was used to identify the determinant factors of reproductive DM. Among the variables included in the model, age, literacy status, number of children, work status, media exposure and harassment or abuse are found to be statistically significant predictors of reproductive DM (see Table 2).

Younger women (15-24 years of age) are 11.0 and 2.7 times more likely than older women (15-49 years of age) to live in a household where the husband dominated both con- traceptive use and MHSU decisions, respectively. Similarly, middle aged women (2534 years of age) are less likely to make the contraceptive use decision alone $(R R R=0.22)$. On the other hand, younger men are 8.9 times more likely to make the MHSU decision on their own.

The finding indicates that literate women do not let their husbands make the decisions alone; rather they make active participation $(\mathrm{RRR}=$ 0.06 for contraceptive use and $R R R=0.21$ for MHSU). They are 3 times more likely to make the MHSU decision on their own. In contrast, literate husbands are more likely to make the MHSU decisions jointly $(R R R=0.008)$.

Women who have one or two children are less likely to grant the contraceptive use DM power to their husbands only; rather they enjoy active participation ( $R R R=0.24)$. Compared to men who have three or more children, those who have one or two children made the decision together with their wives (RRR $=0.12)$. Besides, working women (women generating their own income) are less likely to live in situations where husbands dominated the MHSU $\mathrm{DM}(\mathrm{RRR}=0.23)$.

As far as media exposure is concerned, women who have media access are 3 times more likely to make their own decision on con- 
traceptive use than consulting their husbands, whereas men who have media access are 4.8 times more likely to let their wives decide alone on MHSU.

Compared to harassed or abused women, women who have not been harassed or abused by their husbands are less likely to make the MHSU decisions alone (RRR = 0.39). Similarly, husbands who did not harass or abuse their wives are less likely to leave the MHSU decisions to their wives alone; rather they participate in the $D M$ process $(R R R=0.37)$.

Table 2 Adjusted relative risk ratios (RRR) from multinomial logistic regression model for determinants of reproductive DM

\begin{tabular}{|c|c|c|c|c|c|c|}
\hline \multirow[b]{3}{*}{ Characteristics } & \multicolumn{4}{|c|}{ MHSU DM } & \multirow{2}{*}{\multicolumn{2}{|c|}{$\begin{array}{l}\text { Contraceptive use DM } \\
\text { Women }\end{array}$}} \\
\hline & \multicolumn{2}{|l|}{ Women } & \multicolumn{2}{|l|}{ Men } & & \\
\hline & $\begin{array}{l}\text { Wife vs } \\
\text { Joint }\end{array}$ & $\begin{array}{l}\text { Husband vs } \\
\text { Joint }\end{array}$ & $\begin{array}{l}\text { Wife vs } \\
\text { Joint }\end{array}$ & $\begin{array}{l}\text { Husband vs } \\
\text { Joint }\end{array}$ & $\begin{array}{l}\text { Wife vs } \\
\text { Joint }\end{array}$ & $\begin{array}{l}\text { Husband vs } \\
\text { Joint }\end{array}$ \\
\hline \multicolumn{7}{|l|}{ Age } \\
\hline $15-24$ & 1.06 & $2.70 *$ & 0.56 & $8.90 * *$ & 0.24 & II.00** \\
\hline $25-34$ & 0.48 & 1.50 & 0.88 & 1.50 & $0.22 *$ & 1.00 \\
\hline $35+$ & 1.00 & 1.00 & 1.00 & 1.00 & 1.00 & 1.00 \\
\hline \multicolumn{7}{|l|}{ Literacy status } \\
\hline Literate & $3.00 * *$ & $0.2 I^{* *}$ & 1.60 & $0.008 * *$ & 0.76 & $0.06 * *$ \\
\hline Illiterate & 1.00 & 1.00 & 1.00 & 1.00 & 1.00 & 1.00 \\
\hline \multicolumn{7}{|c|}{ Number of children } \\
\hline No child & & & & & 5.50 & 0.49 \\
\hline $1-2$ & 0.84 & 1.10 & 1.47 & $0.12^{*}$ & 2.10 & $0.24 *$ \\
\hline $3+$ & 1.00 & 1.00 & 1.00 & 1.00 & 1.00 & 1.00 \\
\hline \multicolumn{7}{|l|}{ Work status } \\
\hline Working & 0.66 & $0.23^{* *}$ & & & 1.90 & 0.45 \\
\hline Not working & 1.00 & 1.00 & & & 1.00 & 1.00 \\
\hline \multicolumn{7}{|l|}{ Media exposure } \\
\hline Have access & 1.20 & 0.88 & $4.8^{* *}$ & 0.47 & $3.00 *$ & $0.4 I$ \\
\hline No access & 1.00 & 1.00 & 1.00 & 1.00 & 1.00 & 1.00 \\
\hline \multicolumn{7}{|c|}{ Harassment/abuse } \\
\hline Not committed & $0.39 *$ & 0.69 & $0.37^{*}$ & 0.42 & 1.00 & 0.73 \\
\hline Committed & 1.00 & 1.00 & 1.00 & 1.00 & 1.00 & 1.00 \\
\hline
\end{tabular}

Men contraceptive users were smaller and almost all of them made the decision jointly, as a result, they are not considered in the analysis

\section{Discussion}

The sample characteristics demonstrated the subordinate position of women in the weavers' community. Accordingly, wives are less educated, less likely to have their own income, have a lower exposure to media, younger in age, have poor maternal health service utilization, and are prone to harassment or abuse. Violence against women is a product of gender subordination of women and men's control of DM in the family (Murphy and Ringheim 200I). Moreover, age difference between couples exacerbate gender-based power imbalance (Blanc 200I). Probably due to the gender-bias thinking of the society, women might not have an opportunity to attend school. Besides, the language barriers together with their lower educational status, social status and restricted freedom of movement might have worsened the media consumption habit of women in the study sample.

Younger and middle aged women are less likely to participate in the reproductive DM process. This may be due to the lower bargaining power of younger women coupled with 
their low socio-economic status and information exposure made them to live in the household where husband dominated the DM. This result is in line with the study conducted by Lapeyrouse (2002) that younger women have low bargaining power regarding contraceptive use.

Literate women actively participate in the reproductive DM. Women's education provides them with more opportunity to participate in the process of modernization and enables them to bring about changes in the economic and social situation. This, in turn, improves their knowledge and practice of reproductive health rights and improves their DM power in their household. Moreover, this finding is in agreement with earlier research findings which concluded that education for women positively affects conjugal communication and facilitates egalitarian decision-making (Chapagain 2006; Hossain 1998; Laban and Gwako 1997). Moreover, literate men let their wives made the MHSU decisions. Literate husbands might practise modernity and make the DM floor open for their wives rather than sticking to traditional men-dominant decision-making process.

Having fewer children for women is positively associated with their participation in contraceptive use DM. In a similar way, men who have had fewer children let their wives be involved in the MHSU decisions. The possible explanation for this result is that women who delay or avoid births can bring about significant economic advantages over women with a large number of children when terminating consensual union. Therefore, having fewer children can improve a woman's ability to end an unsatisfactory relationship (Dixon-Mueller 1993) and it enables them to exercise more freedom within marriage. Prasadja et al. (1997) concluded that women with two or fewer children have greater control of their reproductive lives than women with three or more children.

Compared to not-working women, working women (women generating their own income) are more likely to participate in reproductive DM. Having their own income for women increases their economic independence and challenges the traditional belief of men-dominance in DM and hence improves their bargaining power within the household. Cash work and control over earnings for women improves women's autonomy and stimulates spousal com- munication, and hence creates DM power (Chapagain 2006; Hossain 1998; Laban and Gwako 1997; Gage 1995).

Women with media access are more likely to make or participate in reproductive decisions than women with no media access. Besides, men with media access give the upper hand of MHSU DM power to their wives. Exposure to media, especially programs related to family planning, widens the scope of understanding issues related to contraceptive use and helps in the realization of its importance in achieving the desired family size (CSA and ORC Macro 2006). Thus, better media consumption will equip them with information about the reproductive health issues including reproductive health rights and it encourages them to active participation in the reproductive decision-making process in their household.

Women who have not been harassed or abused by their husbands, and husbands who did not harass or abuse their wives, are more likely to make the MHSU decisions jointly. This finding corroborates Chapagain (2006) who concluded that women who experienced violence from their husbands are less likely to participate in antenatal care DM. Moreover, husbands who did not harass or abuse their wives might believe in spousal communication and share the DM power equally.

\section{Conclusion}

The study investigated the gender power relations in reproductive decision-making of Gamo migrant weavers, who are living in Addis Ababa, from the Gamo Gofa zone of Southern Ethiopia. The objectives were assessing the reproductive DM pattern and identifying the determinant factors associated with reproductive DM in the study population. To meet the objectives, respondents were asked a series of questions related to reproductive DM. Finally, the DM patterns were analyzed using multinomial logistic regression.

The result underscored women's empowerment through education and economic activities as one of the entry points for enabling them to actively participate in the reproductive decisionmaking process. Thus, policies which advocate women's empowerment (policies like the National Policy of Ethiopian Women, National 
Population Policy, The Ethiopian Education and Training Policy and Health Policy) should be implemented in a well organized and integrated way. In fact, the study community should also be empowered as they have a lower literacy status. More should be done to strengthen spousal communication and negotiation skills among couples to improve joint reproductive decisionmaking patterns. Moreover, efforts should be made to foster the elimination of gender imbalance and promote gender equality in the study communities, especially among those categories who have reported men-centered reproductive DM (younger, illiterate, not working, no media access, having more than two children and who have victim of physical harassment or verbal abuse).

\section{Acknowledgement}

I would hereby like to acknowledge both the Addis Ababa University and Hawassa University for their financial and material support of this research. I also thank Samson Kassahun (Ph.D), Fikadu Nigussie and Mesay G/Mariam for their assistance and comments.

\section{References}

Arkutu, A. ( $2^{\text {nd }}$ ed) 1995. Healthy Women, Healthy Mothers: An information guide. Family Care International: USA.

Blanc, A.K 200I. "The Effect of Power in Sexual

Relationships on Sexual and Reproductive Health: An Examination of Evidence." Studies in Family Planning 32(3): 189-2 I3.

Boserup, E 1985. "Economic and Demographic Inter-relationships in Sub-Saharan Africa." Population and Development Review II (3):383397.

Central Statistical Agency (CSA) and ORC Macro (2006): Ethiopian Demographic and Health Survey 2005. Addis Ababa, Ethiopia and Calverton, Maryland, USA: Central Statistics Agency and ORC Macro.

Chapagain, M 2006. "Conjugal Power Relations and Couples' Participation in Reproductive Health Decision-Making: Exploring the Link in Nepal." Gender, Technology and Development I0(2): I60-I89.

Dixon-Mueller, R (1993): Population Policy and Women's Right. Westport, Connecticut: Praeger. Eguavoen, A. Sims O. and Godfrey, I 2007. "The Status of Women, Sex Preference, Decision-
Making and Fertility Control in Ekpoma Community of Nigeria." Journal of Social Science I5(I):43-49.

Gage, A.J 1995. "Women's Socio-economic Position and Contraceptive Behavior in Togo." Studies in Family Planning 26(5):264-277.

Hossain, S.Z 1998. "Decision Making, Use of Contraception and Fertility in Bangladesh: a path analysis." International Journal of Sociology and Social Policy 18(7/8):27-55.

Kuponiyi, F.A and Alade, O 2007. "Gender Dynamics and Reproduction Decision Making Among Rural Families in Orire Local Government Area of Oyo State, Nigeria." Journal of social science I5(2): I0I-I04.

Lapeyrouse, L. M (2002): Gender, Power and Culture: Reproductive Decision-Making among Mexican American Youth. Health Behavior and Health Education, University of Michigan: Michigan.

Laban, E. and Moogi, G 1997. "Conjugal Power in Rural Kenya Families: It's Influence on Women's Decision about Family Size and Family Planning Practice." Sex Roles: A Journal of Research.

Makinwa-Adebusoye, P (200I): Sociocultural Factors Affecting Fertility in Sub-Saharan Africa. Workshop on Prospect for Fertility Decline in High Fertility Countries. Population Division, Department of Economic and Social affairs, United Nation Secretariat: New York, 9-I I July 2001.

Murphy, E. and Karin, R (200I): Reproductive Health, Gender and Human Rights: A Dialogue. Women's Reproductive Health Initiatives (WRHI), Path: Washington, DC.

Oladeji, D 2008. "Gender Roles and Norms Factors Influencing Reproductive Behavior among Couples in Ibadna, Nigeria." Anthropologist 10(2): I33-138.

Olokodana, M and Yeshi, H (1998). Gender Equity, Equality and Empowerment of Women. Addis Ababa:Ethiopia.

Prasadja, et al. (1997): In the Shadow of Men: Reproductive Decision-making and Women's Psychological Well-Being in Indonesia. Center of Social Studies at Atma Jaya Catholic University, the Women's Studies Graduate Program at University of Indonesia and Family Health International.

Spizer, I.S Lisa, W. and Marion, C 2005. "Gender Relations and Reproductive Decision Making in Honduras." International Family Planning Perspective 3I(3): I3I-139.

World Health Organization (1999): An Assessment 
of Reproductive Health Needs in Ethiopia. World Health Organization: Geneva.

$\mathrm{Xu}, \mathrm{L}$ 1999. "Gender relations and reproductive decision-making in the context of rural china in the post-reform period." Working Paper Series No. 284. 